\title{
Cartografia Escolar: oficinas didáticas sobre alfabetização e letramento cartográfico para a formação inicial de professores de Geografia
}

\author{
School cartography: didactic workshops on Literacy and Cartographic Literacy for the initial \\ qualification of Geography teachers
}

Guilherme Moreira da Silva Graduação em Geografia Licenciatura Plena pela Universidade Federal de Santa Maria, Brasil guilhermems2010@gmail.com

Nathália Lampert Batista Professora Adjunta no Departamento de Geociências da Universidade Federal de Santa Maria, Brasil natilbatista3@gmail.com

\author{
Carina Petsch \\ Doutora em Geografia pela Universidade Federal de Santa Maria, Brasil \\ carinapetsch@gmail.com
}

\begin{abstract}
Resumo
Este trabalho tem como objetivo geral relatar oficinas pedagógicas sobre Alfabetização e Letramento Cartográfico para dar suporte pedagógico na formação inicial de professores de Geografia. A metodologia foi dividida em quatro oficinas. Na primeira, realizou-se uma reflexão teórica sobre o tema e na segunda, terceira e quarta oficinas, houve a aplicação de atividades práticas por parte dos ministrantes e dos participantes. Os participantes além de apresentarem atividades práticas sobre a temática, debateram aspectos sociais e políticos de seu espaço de vivência. Por meio das respostas dos participantes, concluiu-se que as oficinas apresentaram resultados positivos ao processo de formação docente, contribuindo como suporte didático e metodológico para futuras práticas em sala de aula, e potencialidade de aplicação em diversos contextos de formação inicial de professores de Geografia.
\end{abstract}

Palavras-chave: Ensino de Geografia; Formação docente; Cartografia.

\begin{abstract}
This work has as general objective to report pedagogical workshops on Literacy and Cartographic Literacy to provide pedagogical support in the initial training of Geography teachers. The methodology was divided into four workshops. In the first, there was a theoretical reflection on the topic. In the second, third and fourth workshops, there was the application of practical activities by the lecturers and participants. In addition to presenting practical activities on the subject, the participants debated social and political aspects of their living space. Based on the participants' responses, it was concluded that the workshops presented positive results to the teacher qualification process, contributing as didactic and methodological support for future classroom practices and as a potential application in several contexts of initial training of Geography teachers.
\end{abstract}

Keywords: Geography teaching; Teacher training; Cartography. 


\section{INTRODUÇÃO}

$\mathrm{Na}$ atualidade, podem-se encontrar os produtos cartográficos no cotidiano das pessoas, isto é, em jogos eletrônicos, redes sociais, aplicativos de comunicação, entre outros. Nesse sentido, pensar a Cartografia no contexto da Educação Básica é de suma importância, visto que as noções cartográficas podem contribuir aos estudantes pensarem espacialmente, tornando sujeitos agentes e transformadores de seus espaços inseridos, bem como potencializa a realização de uma leitura crítica e consciente do mapa. Dada a importância da Cartografia no espaço escolar, ela pode ser vista como uma aliada para o ensino de Geografia. Batista et al., (2019), destaca que:

A Cartografia que sempre foi uma grande aliada da Geografia, torna-se ainda mais importante ao ensino e a aprendizagem dessa disciplina. Ela motiva. Ela dinamiza. Ela produz novas leituras de mundo. Ela permite diversificar o olhar sobre as realidades socioambientais do Planeta Terra. Se bem utilizada, permite desenvolver um pensamento espacial capaz de conduzir a leituras críticas da realidade em que se vive e aproximar as leituras temporais e espaciais do cotidiano dos estudantes, fazendo-os se motivarem e desejarem aprender Geografia (Batista et al., 2019, p. 5).

Cavalcanti (2002, p. 16), ainda destaca que a Cartografia "não é um conteúdo a mais no ensino de Geografia; ele perpassa todos os outros conteúdos, fazendo parte do cotidiano da matéria". Contudo, o uso da Cartografia na maioria das escolas ocorre somente de forma esporádica e pouco aprofundada (ARAGÃO, 2010). Sendo assim, é fundamental procurar desenvolver oficinas pedagógicas e metodologias que possam estimular os docentes a utilizarem os conceitos da Cartografia Escolar, valorizando os espaços de vivências dos estudantes, e atribuindo aos sujeitos a leitura consciente dos espaços geográficos. É importante trabalhar essas noções durante a formação inicial de professores, a fim de valorizar a Cartografia como metodologia indispensável durante a prática docente. Todavia, poucos são os cursos superiores de Geografia que atribuem em seus currículos o debate sobre a Cartografia Escolar (RICHTER, 2017).

O presente estudo possui como problema de pesquisa: "Como aplicar oficinas didáticas de Cartografia Escolar para a formação inicial de professores de Geografia? Evidencia-se que diversos estudos, tais como a de Oliveira (2017, p. 226), constatam que ainda há falta de formações para professores que trabalhem com noções cartográficas, conforme aponta o autor "há ainda deficiências dos próprios profissionais da educação, quanto à formação e capacitação, seja na área específica da Cartografia ou mesmo no campo da informática". Portanto, o objetivo deste trabalho é desenvolver uma série de oficinas com professores em formação de Geografia da Universidade $\mathrm{X}^{1}$ buscando: (i) identificar os conhecimentos prévios dos participantes da pesquisa sobre Cartografia Escolar e formação de professores; (ii) elaborar com os participantes da pesquisa a criação de atividades práticas sobre Alfabetização e Letramento Cartográfico na formação inicial docente; e

\footnotetext{
${ }^{1}$ Omitido para a avaliação
} 
(iii) analisar a contribuição das práticas pedagógicas ativas desenvolvidas durante as oficinas pedagógicas e sua potencialidade de aplicação na Educação Básica.

\title{
2. CARTOGRAFIA ESCOLAR: ALFABETIZAÇÃO E LETRAMENTO CARTOGRÁFICO
}

No Brasil, a Cartografia Escolar teve seu início com o trabalho desenvolvido por Lívia de Oliveira em 1978, o qual em sua obra intitulada de "Estudo metodológico e cognitivo do mapa". A autora se baseou nos estudos de Jean Piaget e enfatizou a necessidade de uma metodologia que auxiliasse o docente em ensinar Geografia com o uso consciente do mapa, ou seja, que o mesmo compreenda a ciência presente no mapa e consiga relacioná-la em seu cotidiano. A partir desse trabalho, a Cartografia Escolar se estabelece como um conhecimento construído na interface entre Cartografia, Educação e Geografia, sendo ela responsável em abranger noções relativas ao espaçotempo social, além de concepções teóricas de diferentes áreas do conhecimento sob a ótica de variados contextos culturais (ALMEIDA, 2011).

A Cartografia Escolar tem como objetivo fomentar a compreensão, uso e elaboração de mapas em sala de aula. A partir disso, em meados da década de 1990 iniciou-se no Brasil o boom da Cartografia Escolar em simpósios, congressos e fóruns. Nesse sentido, essa área foi se concretizando como uma linha de pesquisa dentro da ciência cartográfica, além de promover debates relacionados a representações espaciais, metodologias de ensino, uso de tecnologias e produção de materiais didáticos sobre a temática (ALMEIDA, 2014). No que se refere a presença da linguagem cartográfica em espaços escolares, Cavalcantti (2002, p. 16) coloca que:

\begin{abstract}
A habilidade de orientação, de localização, de representação cartográfica e de leitura de mapas desenvolve-se ao longo da formação dos alunos. Não é um conteúdo a mais no ensino de Geografia; ele perpassa todos os outros conteúdos, fazendo parte do cotidiano da matéria. Os conteúdos de cartografia ajudam a responder àquelas perguntas: Onde? Por que este lugar? Ajudam a localizar fenômenos, fatos e acontecimentos estudados e a fazer correlações entre eles, são referências para o raciocínio geográfico. (CAVALCANTI, 2002, p. 16).
\end{abstract}

A partir do exposto, no ensino de Geografia, o entendimento cartográfico assume um papel vital como uma linguagem a ser trabalhada e construída perante a realidade discente. Logo, a Alfabetização e Letramento Cartográfico se apresentam como elementos necessários no processo de formação escolar, cujo objetivo é desenvolver competências e habilidades de interpretação do espaço vivido a partir das representações cartográficas, bem como tornar o estudante como sujeito na técnica de leitura e elaboração de documentos cartográficos (SANTOS, 2017). Os termos Alfabetização e Letramento possuem forte influência nas ciências linguísticas. Porém, nos debates referentes a didática em Geografia e ensino de Cartografia, esses conceitos obtiveram importância para entender a análise e compreensão do espaço geográfico. Dessa forma, pode-se destacar 
Oliveira (1978) e Simielli (1996) como as referências ao uso do termo Alfabetização na Geografia escolar brasileira.

Martinelli (1999) caracterizava o termo Alfabetização como "a metodologia de ensinar crianças a ler o espaço, representá-lo para tornar-se leitor eficiente do espaço em escala local e global". Mas, durante a década de 1990 e 2000, com o advento do termo Letramento na área linguística, os geógrafos especialistas na área de ensino de Cartografia começaram a utilizar em suas pesquisas o termo "Letramento "como sinônimo de Alfabetização, desconsiderando o significado etimológico dos termos empregados pela linguística (BREDA, 2017). Com o objetivo de esclarecer a diferença dos termos, Breda (2017) apresenta um quadro com a etimologia dos conceitos, a fim de compreender esses vocábulos e caracterizar a diretriz de cada denominação (Figura 1).

\begin{tabular}{|c|c|c|c|c|}
\hline \multirow{4}{*}{$\mathrm{a}(\mathrm{n})$} & \multirow{4}{*}{ alfabet } & \multicolumn{2}{|c|}{0} & Que não conhece o alfabeto, que não sabe ler e escrever \\
\hline & & \multicolumn{2}{|c|}{$\begin{array}{c}\text { ismo } \\
\text { (modo de pensar) }\end{array}$} & Estado ou condição de analfabeto \\
\hline & & \multicolumn{2}{|c|}{$\begin{array}{c}\text { izar } \\
\text { (fazer com que) }\end{array}$} & Ensinar a ler e a escrever \\
\hline & & $\mathrm{iza}(\mathrm{r})$ & $\begin{array}{l}\text { ção } \\
\text { (ação) }\end{array}$ & Ação de alfabetizar \\
\hline \multirow[t]{3}{*}{$\mathrm{i}$} & \multirow{3}{*}{ letra } & \multicolumn{2}{|c|}{ do } & Que não tem conhecimento literário \\
\hline & & \multicolumn{2}{|c|}{ do } & Versado em letras (literatura, línguas), erudito \\
\hline & & \multicolumn{2}{|c|}{$\begin{array}{c}\text { mento } \\
\text { (resultado da ação) }\end{array}$} & Resultado da ação de letramento \\
\hline
\end{tabular}

Figura 1 - Etimologia do termo Alfabetização e Letramento. Fonte: BREDA 2017, p.137.

Nessa perspectiva, Breda (2017) caracteriza que a Alfabetização corresponde ao ensino da língua e o Letramento aos processos complexos e ativos da linguagem. Com isso, ela enfatiza a Alfabetização como uma metodologia auxiliadora para leitura e escrita de um indivíduo e o Letramento como uma aplicação dessa aprendizagem em seu meio, ou seja, de acordo ao contexto social e cultural de cada indivíduo, valorizando suas experiências e percepções. Faraco (2008), professor e linguista brasileiro, ao relacionar os termos, caracteriza a Alfabetização como conhecimento do alfabeto, da lógica e dos mecanismos da escrita alfabética, e letramento como a aplicação na cultura escrita em suas diversas faces e no domínio de suas práticas socioculturais.

Ademais, Breda (2017) sugere a utilização do termo alfabetizar letrando, em que ensinar a ler e a escrever está contextualizado às práticas sociais da leitura e escrita. Assim, a partir do entendimento do conceito de Alfabetização e Letramento, é importante caracterizá-los no ensino de Cartografia, e verificar como cada conceito potencializa a compreensão espacial e interpretação das representações cartográficas.

A Alfabetização Cartográfica está bastante ligada ao ensino-aprendizagem dos anos iniciais da Educação Básica. Todavia, é importante reforçar essa noção nos anos finais do Ensino Fundamental, período que a Geografia já é consolidada como disciplina obrigatória, e também no 
Ensino Médio, a fim de potencializar o ensino de Cartografia e suprir possíveis carências de aprendizagem oriundas durante a formação discente. Com isso, a construção dessa metodologia teve forte influência pelos estudos de Oliveira (1978), Simielli (1999), Almeida (2001) e Passini (2012), os quais contribuíram para disseminação e divulgação dessa temática no meio científico (RICHTER, 2017).

\section{METODOLOGIA}

O presente estudo se apresenta com um enfoque na abordagem qualitativa, pois busca entender a natureza de um fenômeno espacial e compreender esse fenômeno em seus processos dinâmicos por grupos sociais, sendo necessário a comunicação do pesquisador com os membros do estudo durante a produção do conhecimento (RICHARDSON, 1985). Dessa forma, ao desenvolver as oficinas pedagógicas sobre Alfabetização e Letramento Cartográfico e verificar a contribuição dessas ações sobre os sujeitos da pesquisa, os resultados serão debatidos qualitativamente, validando todas informações e momentos vivenciados perante a prática realizada.

O método utilizado foi o descritivo, cujo foco de estudo permite conhecer os participantes, seus traços característicos, seus conhecimentos prévios e indagações sobre a temática, bem como é o método mais utilizado no campo de ensino e educação (TRIVIÑOS, 2006). Dessa forma, a seguir, apresentam-se os sujeitos da pesquisa e os procedimentos metodológicos realizados durante a investigação da questão levantada sobre o trabalho científico.

\subsection{Os sujeitos da pesquisa}

Para o desenvolvimento do trabalho, adotou-se como sujeitos da pesquisa um grupo de estudantes do curso de Geografia Licenciatura Plena da Universidade $X^{2}$. Convém destacar, que foi feito o convite para alunos das disciplinas de Cartografia Geral e alunos participantes do Programa Institucional de Bolsa de Iniciação à Docência (PIBID), e conforme o interesse em participar da intervenção, iniciou-se a parte prática.

A escolha desse público-alvo se deu em razão que os participantes do PIBID atuam diretamente em espaços escolares por meio de oficinas pedagógicas, sendo necessário pensar a linguagem cartográfica como metodologia didática em suas práticas. Já a escolha dos graduandos da disciplina de "Cartografia Geral" se deu na perspectiva que não havia no atual currículo do curso uma disciplina voltada exclusivamente para Cartografia Escolar. Logo, a aplicação prática com o público acarretou uma possibilidade metodológica para eles possuírem contato com a Cartografia

\footnotetext{
2 Durante a apresentação do projeto do presente estudo, o professor regente do PIBID e um pós-doutoranda manifestaram interesse em participar das oficinas pedagógicas. Dessa forma, participaram de todo processo metodológico junto aos sujeitos da pesquisa.
} 
voltada ao Ensino de Geografia. Dada a apresentação do trabalho, foi fechado um total de quatorze sujeitos da pesquisa.

\title{
3.2. Procedimentos metodológicos
}

Para desenvolver as oficinas pedagógicas com os sujeitos da pesquisa, primeiramente realizou-se uma revisão bibliográfica sobre a temática, visando aprimorar os conhecimentos da área e fundamentar a proposta metodológica do trabalho. Dessa forma, foi feito um levantamento e leitura de estudos científicos referentes a Cartografia Escolar, Formação de professores em Geografia e Alfabetização e Letramento Cartográfico. A metodologia escolhida para aplicação de oficinas pedagógicas foi fundamentada na proposta de Simielli (1999) sobre Alfabetização Cartográfica. A autora destaca que:

\begin{abstract}
Algumas noções são básicas na alfabetização cartográfica, tais como: a visão oblíqua e a visão vertical, a imagem tridimensional e a imagem bidimensional, o alfabeto cartográfico (ponto, linha e área), a construção da noção de legenda, a proporção e a escala, a lateralidade, referências e orientação espacial. O desenvolvimento dessas noções contribui para a desmistificação da cartografia como propositora de mapas prontos e acabados no ensino fundamental e médio (SIMIELLI, 1999, p.77).
\end{abstract}

No entanto, com o advento do meio tecnológico nos espaços escolares e no cotidiano da população, podemos acrescentar as geotecnologias nessa lista, cujo objetivo de seu uso, tende a dinamizar as aulas de Geografia e auxiliar na atuação dos estudantes sobre o mundo globalizado (RIZZATTI, 2016). Assim, para trabalhar Alfabetização e Letramento Cartográfico foram selecionados os eixos temáticos (Figura 2): A (noções de alfabeto cartográfico, tipos de visões, tipos de imagens, lateralidade, orientação), B (proporção, escala, legenda), C (coordenadas geográficas e projeções cartográficas) e D (gráficos, cartogramas e geotecnologias).

A metodologia resultou no desenvolvimento de uma sequência de quatro oficinas didáticas aplicadas por meio de um curso de extensãa $o^{3}$ :

\footnotetext{
${ }^{3}$ Entende-se como cursos de extensão, atividades acadêmicas que não estão inclusas no currículo da graduação. É, portanto, uma atividade complementar que permite ao aluno se aprofundar em seu campo de atuação, enriquecendo seus conhecimentos (BOSCO, 2018).
} 


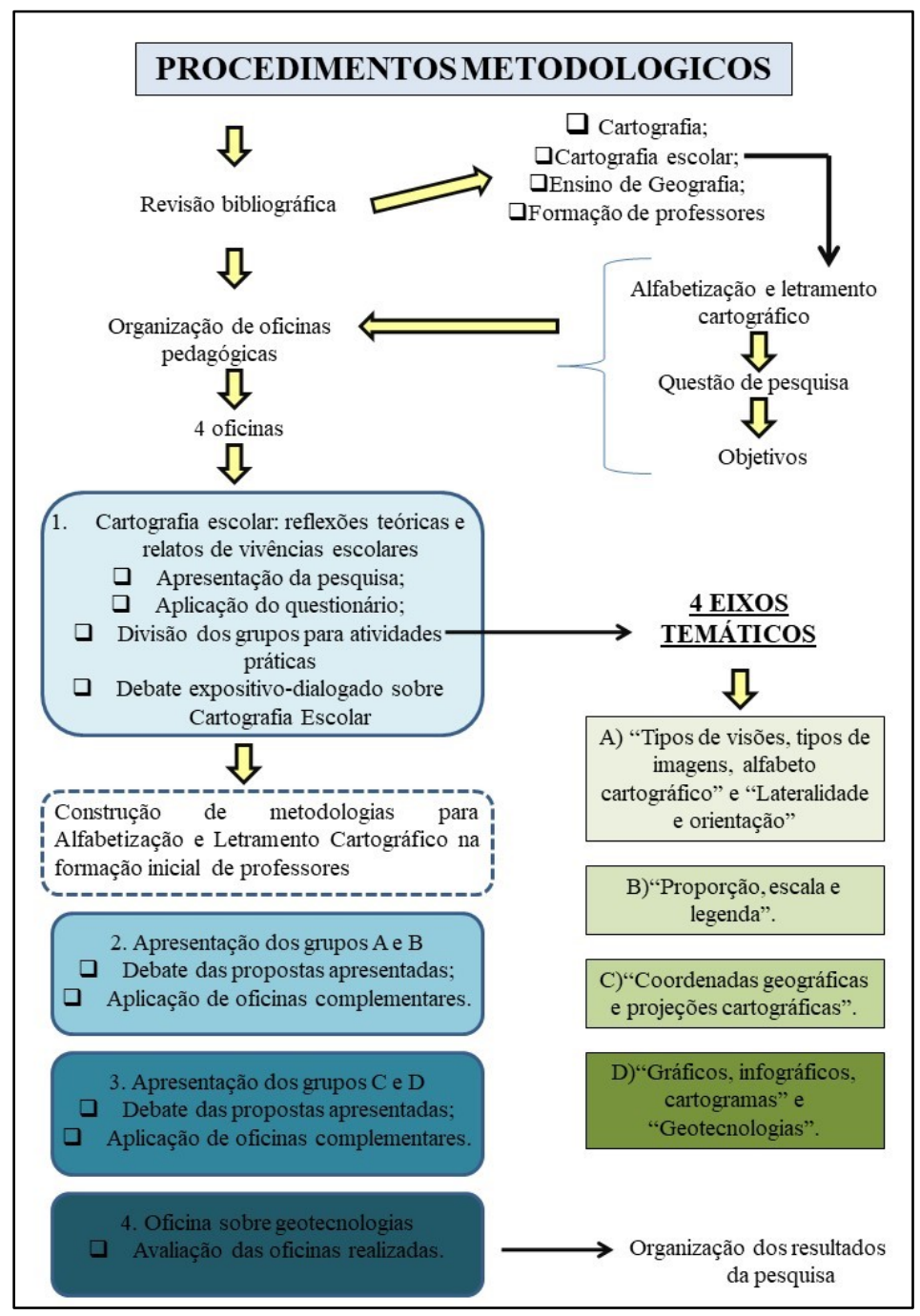

Figura 2: Fluxograma dos procedimentos metodológicos

Oficina 1: foi feita uma caracterização do projeto desenvolvido no trabalho e aplicado um questionário com o objetivo de conhecer os sujeitos da pesquisa. O questionário foi dividido em duas seções. Na seção "Caracterização dos participantes", as perguntas presentes no questionário analisaram cinco variáveis: (1) Gênero; (2) Semestre que está no curso; (3) Idade; (4) Participação ou não em projetos de iniciação à docência; (5) Experiência e/ou atuação na prática docente. $\mathrm{Na}$ seção Cartografia Escolar, foi posto quatro perguntas elaboradas pelo pesquisador: "Como você define a Cartografia Escolar enquanto vivência escolar?"; "Você vê a importância da Cartografia no Ensino de Geografia?"; "Na Educação Básica, você tinha dificuldade em conteúdos relacionados à linguagem cartográfica?"; "Nas aplicações de atividades na escola, já se deparou com alguma prática envolvendo Cartografia?". Com base no debate a partir das perguntas anteriormente citadas, foi realizada uma nuvem de palavras utilizando o software WordClous ${ }^{4}$. Após a aplicação do

\footnotetext{
${ }^{4}{ }^{4}$ Wordclouds corresponde em um software on-line que elabora nuvem de palavras de acordo com a temática proposta pelo usuário. Assim, na construção do banco de dados a palavra que é repetida constantemente, isto é, com maior número de vezes, é representada com maior proporção de tamanho na representação final, conforme é ilustrada na figura. As cores presentes nas palavras são geradas pelo software, não configurando significado as palavras.
} 
questionário, foi entregue aos participantes um roteiro das oficinas didáticas, apresentando as datas dos próximos encontros, além das propostas que seriam realizadas no decorrer do curso (Figura 2). A partir da aplicação e análise do questionário, o encontro contemplou a realização de um debate expositivo-dialogado sobre as noções teóricas da Alfabetização e Letramento Cartográfico. Ao final da oficina foi feita a divisão dos grupos para criação de atividades práticas, segundo os eixos temáticos.

Oficina 2 e 3: corresponderam a apresentação das atividades realizadas pelos participantes sobre os quatro eixos temáticos divididos na primeira oficina, além da entrega de planos de aula referentes a cada tema. Destaca-se que nas oficinas 2 e 3 houve uma sequência metodológica a partir da criação de atividades práticas com os sujeitos de pesquisa sobre Alfabetização cartográfica, a exposição de metodologias didáticas já realizadas sobre a temática o qual potencializam a linguagem cartográfica no âmbito escolar, e por fim, o debate e aplicação das atividades criadas e metodologias apresentadas nas oficinas;

Oficina 4: a última oficina didática do curso de extensão apresenta dois momentos: (1) Elaboração de mapas com o uso das geotecnologias, especificamente o Sistema de Informação Geográfica (QGIS); e (2) Avaliação final das práticas desenvolvidas. Nesse sentido, no primeiro momento foram feitos os Mapas Coropléticos referentes à população total, população de homens e população de mulheres de Santa Maria/RS, ou seja, realização dos mapas feitos manualmente no encontro anterior, sobre o aporte das geotecnologias. O segundo momento correspondeu a avaliação de toda prática desenvolvida, com o objetivo de analisar se as oficinas contribuíram ou não para a formação docente, bem como suas percepções em relação a metodologia desenvolvida. Novamente, foi realizada uma nuvem de palavras com os termos citados pelos alunos neste debate final.

Para auxiliar a criação de atividades práticas referentes aos eixos temáticos, foi entregue aos grupos um modelo de Plano de Aula, sendo necessário explicar as partes desse documento, a fim de contribuir para uma prática pedagógica eficiente. Convém destacar ainda que para cada encontro realizado foi feito um convite virtual nas redes sociais, com auxílio de um folder, o qual apresentava a dinâmica que seria realizada durante a oficina. Além disso, para facilitar a comunicação entre o pesquisador e os sujeitos da pesquisa, foi feito um grupo na plataforma virtual denominada Google Sala de Aula, a fim de compartilhar textos e ideias referentes à temática abordada durante o curso de extensão. 


\section{RESULTADOS E DISCUSSÕES}

Neste capítulo serão apresentados os resultados referentes a pesquisa. Para melhor compreensão, junto à descrição, apresenta-se a reflexão acerca dos acontecimentos sobre a aplicação, isto é, os diálogos, perspectivas e questionamentos que os participantes apresentaram em cada parte do curso de extensão.

\subsection{Oficina didática 1 - Cartografia escolar: reflexões teóricas e relatos de vivências escolares}

No primeiro momento, com o objetivo de contextualizar a Cartografia Escolar, bem como o papel do professor de Geografia na contemporaneidade, foram feitas três perguntas para os participantes: "Quem (realmente) deseja ser professor? Por quê?”; "Como se tornar professor de Geografia?”; “Qual a importância da Cartografia no Ensino de Geografia?”. Esses questionamentos validaram a contextualização da temática e trouxeram um debate acerca da realidade dos participantes, em relação à licenciatura em Geografia.

Por meio das respostas, foi possível verificar que muitos enfatizaram o papel do professor de Geografia no contexto social dos estudantes e da escola, isto é, do espaço em que a escola está inserida e a realidade que caracteriza essa relação, além do papel desse profissional acerca das mudanças econômicas, políticas e sociais presentes em nosso território. Ademais, alguns participantes relataram que "se tornar professor de Geografia só ocorre na prática", e que é por meio das vivências nesse espaço, na realização e prática em sala de aula, que o professor se estrutura enquanto docente. Esses levantamentos foram de suma importância durante o encontro, visto que contribuíram para o debate sobre formação de professores, bem como validou a proposta do estudo em pensar as oficinas visando diretamente a prática docente. Nesse mesmo momento, quando foi perguntado sobre "Quem (realmente) deseja ser professor?”, observou-se que muitos participantes relataram que ingressaram no curso de licenciatura por meio do apreço pela profissão e, consequentemente, "inspiração de professores de Geografia" que tiveram ao longo da Educação Básica.

No segundo momento, foi entregue um papel para eles escreverem ou desenharem algo que remetesse à Cartografia que tiveram na escola. As palavras mais citadas estão dispostas na figura 3. Esse momento servirá como reflexão acerca da realização da última oficina, cuja finalidade é verificar se houve mudança ou não sobre a compreensão cartográfica dos participantes, ou seja, se as múltiplas possibilidades que a Cartografia potencializa para o desenvolvimento do ensinoaprendizagem discente foram aceitas pelos participantes da oficina. 


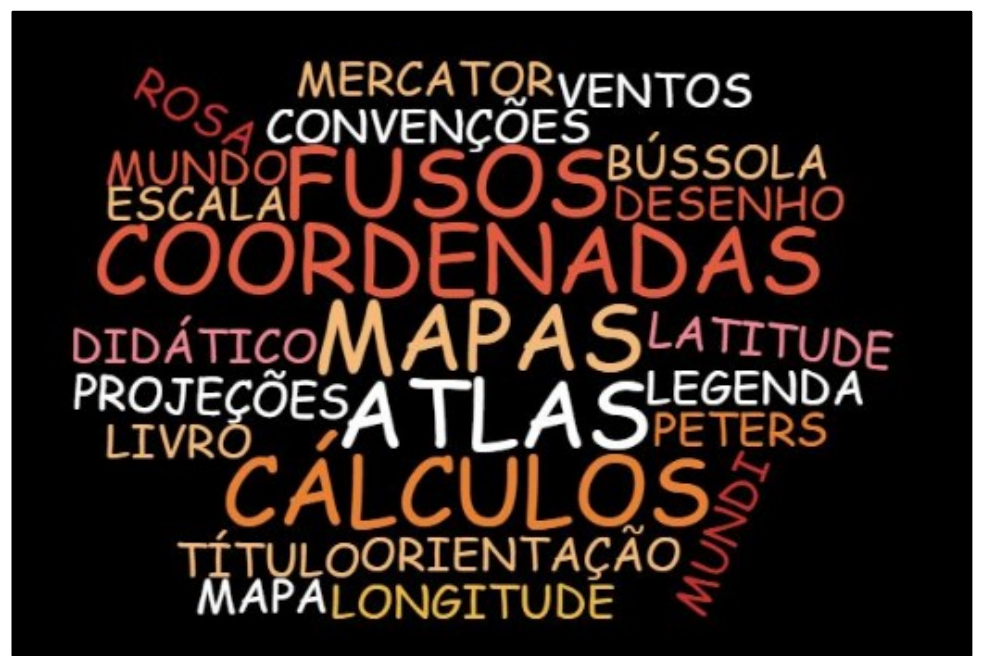

Figura 3 - Principais palavras referentes as experiências dos sujeitos da pesquisa com a linguagem cartográfica durante a Educação Básica.

Fonte: Organizado pelo autor, no software Wordclouds.

Durante a realização dessa prática, os participantes abordaram a carência metodológica da Cartografia durante seus estudos na Educação Básica. Assim, reforçaram que em diversos momentos, a linguagem cartográfica se resumia a pintar mapas e redesenhar as representações presentes em atlas geográfico. Nesse momento, apenas uma participante relatou que houve uma Cartografia mais aprofundada, principalmente com noções de fusos horários, projeções e coordenadas geográficas. Nesse sentido, Simielli (1999, p. 107), avalia a questão da cópia de mapas e destaca que a Cartografia deve "deixar para trás a época em que se copiavam mapas, pela simples razão de copiá-los”. Sobretudo, conforme Castellar aponta sobre a Cartografia “(...) implica utilizála em todos os conteúdos da geografia, para identificar e conhecer não apenas a localização dos países, mas entender as relações entre eles, compreender os conflitos e a ocupação do espaço (CASTELLAR, 2005, p. 216)". Logo, os participantes relataram que possuem dificuldades em determinados assuntos da Cartografia, sendo preciso revisá-los com maior grau de clareza e detalhes.

No terceiro momento da primeira oficina, foi apresentada a teoria sobre Alfabetização e Letramento Cartográfico. Logo, foi comentado sobre os principais autores que trabalharam com a temática, bem como as principais características referentes a essas noções e sua importância a serem trabalhadas nas aulas de Geografia. Destaca-se que os alunos relataram desconhecer a teoria, embora todos acreditam que teria um grande potencial para sua vida acadêmica e como futuros professores.

\subsubsection{Análise dos questionários}

A seguir é apresentado o Quadro 1 que corresponde a caracterização dos participantes da pesquisa. A maioria dos participantes (9) estavam cursando a disciplina de Cartografia Geral, sendo 
que 10 estavam envolvidos com o PIBID. Somente um participante já estava atuando como professor.

Quadro 1: Caracterização dos sujeitos da pesquisa obtido pela aplicação de questionário.

\begin{tabular}{|c|c|c|c|c|}
\hline \multicolumn{5}{|c|}{ Caracterização dos sujeitos da pesquisa } \\
\hline Questionamentos & \multicolumn{4}{|c|}{ Respostas - Em relação aos 14 integrantes } \\
\hline Gênero ( ) Masculino / ( ) Feminino / ( ) Outro & \multicolumn{2}{|c|}{ (05) Masculino } & \multicolumn{2}{|c|}{ (09) Feminino } \\
\hline Semestre que está cursando no curso de Geografia & \multicolumn{2}{|c|}{ (09) $2^{\circ}$ semestre } & \multicolumn{2}{|c|}{$(05) 4^{\circ}$ semestre } \\
\hline Faixa etária & (03) 18 & (03) 20 & (04) 21 & (04) 24 \\
\hline Participa de projetos de iniciação à docência? & \multicolumn{2}{|c|}{ (10) $\mathrm{Sim}$} & \multicolumn{2}{|c|}{ (04) Não } \\
\hline Atua na profissão? & \multicolumn{2}{|c|}{ (01) Sim } & \multicolumn{2}{|c|}{ (13) Não } \\
\hline
\end{tabular}

Com base nos resultados do questionário, algumas considerações podem ser feitas. No que se refere ao semestre que os participantes estão cursando, pode-se analisar que há predominância em graduandos do segundo semestre do curso de Geografia. Esse semestre corresponde ao primeiro contato que os estudantes do curso possuem com as disciplinas pedagógicas e com a disciplina de Cartografia. Dessa forma, a participação nas oficinas didáticas oferecidas pelo presente trabalho pode contribuir com debates e relações correspondentes a essas disciplinas regulares da grade curricular do curso.

Outro fator importante para destacar é a variação da faixa etária dos sujeitos da pesquisa. Conforme é apresentado no Quadro 1, a faixa etária varia entre 18 e 24 anos, fato que ilustra que alguns participantes saíram há pouco tempo da Educação Básica, embora conforme discutido na seção anterior, não tiveram contato com a linguagem cartográfica. Além disso, fica evidenciado que $71 \%$ do grupo participa de projetos de iniciação à docência, ocasionando um conhecimento prévio sobre organização de planos de aula e oficinas pedagógicas. O item gênero e faixa etária não correspondeu significância durante o desenvolvimento da pesquisa.

Na seção "Cartografia Escolar", os questionamentos tiveram como objetivo analisar quais os conhecimentos prévios os participantes possuem acerca da Cartografia Escolar, bem como visualizar suas experiências com a temática durante a Educação Básica, seja como estudante, seja como prática de iniciação à docência. Para ilustrar a interpretação desses dados, foram selecionados alguns questionários a fim de visualizar diferentes pensamentos e pensar estratégias para elaboração de futuras oficinas didáticas (Quadro 2). 
Quadro 2: Apresentação de algumas respostas dos sujeitos de pesquisa no questionário aplicado. Os textos foram copiados na íntegra dos questionários.

Principais respostas da segunda seção do questionário preliminar - Cartografia Escolar

1) Como você define a Cartografia Escolar enquanto $\quad$ 2) Você vê a importância da Cartografia no Ensino de vivência na escola?

Geografia?

a) Área da Geografia que introduz o estudante a pensar criticamente o mapa e conseguir se localizar no espaço geográfico.

b) Permite conhecer os conhecimentos e vivências do aluno em relação ao seu espaço.

c) Tema importante para trabalhar nas aulas de Geografia, porém complicado de pensar atividades interessantes.

d) Tema não valorizado como importante na escola, pois ao analisar minha experiência quanto aluno, a Cartografia foi abordada de forma muito rasa e sem relação com os demais assuntos.

3) Na Educação Básica, você tinha dificuldade em conteúdos relacionados a linguagem cartográfica? Se sim, qual?

a) Sim, principalmente em escala e fusos horários.

b) Na Educação Básica não tive contato com Cartografia. $\mathrm{O}$ acesso desse conhecimento se deu na graduação em Geografia, o que tenho bastante dificuldade de entender. c) Na Educação Básica foram poucas as oportunidades de trabalhar com a Cartografia. O trabalho limitava-se a pintar mapas e localizar lugares no mapa.

d) Um pouco em relação a escala e coordenadas. a) É importante devido a necessidade da Geografia em decorrer ao uso dos mapas para entender determinado fenômeno espacial.

b) Sim, pois os assuntos cartográficos também impactam o cotidiano dos alunos.

c) Considero o ensino de Cartografia essencial, na medida que, os alunos conhecem seu espaço e conseguem de diferentes formas representá-lo, bem como torná-los críticos frente a realidade colocada. d) Sim, pois ambas caminham juntas. A Cartografia como auxílio de interpretação dos conteúdos da Geografia, ocasionando o entendimento do conjunto.

4) Nas aplicações de atividades na escola, já se deparou com alguma prática envolvendo Cartografia? Apresentou dificuldades? Se sim, qual?

a) Sim, no estudo de coordenadas geográficas.

Dificuldade foi encontrar uma didática adequada.

b) Sim, em conjunto com uma colega desenvolvemos uma atividade de projeções cartográficas. Porém a atividade foi interrompida, pois os alunos apresentaram grande dificuldades.

c) Não desenvolvi atividade em razão da dificuldade de explicar.

d) Não, meu grupo ainda não pensou em atividades envolvendo especificamente Cartografia.

Conforme apresentado o Quadro 3, algumas considerações podem ser feitas. No que se refere a definição da Cartografia Escolar os integrantes do trabalho remetem a linguagem cartográfica como um tema importante. Todavia, fundamentam-se apenas como uma linguagem ligada exclusivamente ao mapa e orientação espacial, bem como uma linguagem não valorizada no cotidiano escolar, conforme apontado no primeiro diálogo estabelecido com os participantes. Possivelmente, a Cartografia acaba sendo sinônimo somente de localização. De acordo com Cavalcanti (2002), a Cartografia deve responder as perguntas “Onde? Por que este lugar?”, mas também estabelecer correlações entre os fenômenos, fatos e acontecimentos (CAVALCANTI, 2002). Um dos participantes ainda relata que "é complicado de pensar atividades interessantes", ou seja, os professores em formação não possuem segurança em relação à temática a ponto de sentirem confortáveis para desenvolver alguma atividade prática. Contudo, todos os participantes apontam a importância da Cartografia no ensino de Geografia.

Nas perguntas do questionário 3 e 4 (Quadro 3) percebe-se que os participantes apresentam dificuldades em compreender a ciência durante suas experiências na Educação Básica, dificuldades principalmente nas noções cartográficas que utilizam a matemática em sua aplicação. Bona et al., (2020, p. 327), destacam que “os conceitos matemáticos necessários para o aprendizado da 
Cartografia, acabam criando uma insegurança em professores para trabalhar esse assunto". Além disso, essa carência metodológica de Cartografia, reflete em suas práticas atuais nos projetos de iniciação à docência, o qual é relatado a difículdade de utilizar uma didática que contribua para uma boa práxis voltada a Cartografia.

O desenvolvimento da primeira oficina pedagógica sobre “Alfabetização e Letramento Cartográfico" ocasionou aos sujeitos da pesquisa a reflexão das noções referentes a temática, contribuindo ao debate por meio de suas experiências e perspectivas quanto futuro docentes. Nessa perspectiva, pensar uma oficina introdutória, o qual coloca os participantes como sujeitos do processo na aprendizagem, colabora para a eficácia da oficina quanto ao seu objetivo proposto.

Além disso, conforme verificado nos conhecimentos prévios dos participantes, é notável a dificuldade de pensar a Cartografia Escolar enquanto didática a ser trabalhada em sala de aula. Assim, por meio de um encontro onde determinado grupo de pessoas está disposto a pensar estratégias metodológicas que visam suprir essa carência, é essencial para quebrar o ciclo que permeia o ensino da linguagem na Educação Básica. Dessa forma, a metodologia criada para o primeiro encontro, em sua prática, contribuiu no processo da formação inicial dos professores.

\subsection{Oficina didática 2 - Construção de atividades sobre alfabetização e letramento cartográfico}

Para desenvolver essa temática "Tipos de visões, tipos de imagens, alfabeto cartográfico, lateralidade e orientação" na Educação Básica, o grupo de participantes apresentou uma atividade inspirada em um programa de auditório intitulado de "Mega Senha". Assim, a atividade consiste em trabalhar os conceitos teóricos das noções cartográficas presente no eixo temático, isto é, entender as principais palavras que norteiam esses assuntos, como por exemplo, os termos bidimensional e tridimensional que são utilizados para se referir a noção cartográfica de tipos de imagens. O grupo entregou o plano de ensino.

O jogo "Mega Senha" consiste em uma atividade a ser desenvolvida por dois jogadores, em cada rodada de execução, e cartelas de palavras referentes a temática. Dessa forma, um jogador escolhe uma cartela e ao ler a palavra presente nela, começa a dar dicas sobre características que remetem a essa palavra. O objetivo é que o outro jogador descubra a palavra que remete as características ditas pelo jogador em um curto prazo de tempo.

Convém destacar, que normalmente as características ditas pelo jogador refere-se a antônimos e sinônimos da palavra sorteada, a fim de facilitar o entendimento do jogo. Para exemplificar a explicação, imagina-se que determinado jogador sorteou a palavra "esquerda", uma

\footnotetext{
${ }^{5}$ Programa de televisão desenvolvido pelo canal RedeTV, cujo objetivo é a realização de um jogo em que cada participante joga quatro rodadas, dando pistas e adivinhando as respostas com os dois convidados especiais do programa.
} 
noção presente no conceito de lateralidade. A partir desse termo, o jogador precisa automaticamente pensar nominações que remetem a características desse termo, até que o outro jogador descubra a palavra sorteada. Como o nosso exemplo é o termo "esquerda", pode-se usar termos como "direita" (antônimo) e "canhoto", para o outro jogador chegar à palavra sorteada.

A atividade foi realizada por todos os participantes e foram sorteados os termos longitude, colaterais e direita. Durante a aplicação da atividade, evidenciou-se que alguns participantes tiveram dificuldades de pensar características referentes aos termos que haviam tirados para o desenvolvimento do jogo. Com isso, levantou-se o debate que para a atividade ser desenvolvida no espaço escolar precisa anteriormente ser trabalhado, em caráter de aprofundamento, os conceitos que irão estar presente durante o jogo, a fim de ocasionar subsídios para os jogadores.

Isso posto, os participantes relataram que a atividade pode ser desenvolvida como uma estratégia de revisão de conteúdos na escola, tornando esse momento marcado por uma atividade lúdica e de integração discente. Além disso, os sujeitos da pesquisa relataram que o jogo "Mega Senha" pode ser aplicado em qualquer conteúdo presente na Geografia, pois dinamiza a aula e proporciona ao aprofundamento dos conceitos e características referentes a temática trabalhada, como por exemplo, a aplicação desse jogo para trabalhar questões voltadas a geopolítica e sistemas econômicos.

Com o objetivo de pensar em atividades que envolvessem as noções de proporção, escala e legenda, o segundo grupo pensou em uma atividade na qual os estudantes fariam, manualmente, o mapa do bairro ou escola, onde a atividade poderá ser aplicada e, a partir desse desenho, trabalhariam os principais elementos pertencentes no mapa, enfatizando a proporção, escala e a construção da legenda. Nesse sentido, a atividade mostraria aos discentes que o espaço representado no papel foi reduzido quanto ao seu tamanho no mundo real, sendo assim, com essa reflexão, os estudantes compreenderiam previamente a concepção de escala cartográfica. O grupo não realizou prática em relação a atividade pensada, isto é, apenas comentaram suas ideias expostas, além disso, o grupo não entregou o Plano de Aula. O grupo relatou que tem dificuldade com os conceitos de proporção e que não se sentiam confortáveis em realizar a prática, visto que o conceito de escala apesar de ser fundamental na elaboração e interpretação de mapas, além de exigir conhecimento matemático, necessita de abstração em seu entendimento. Além disso, o conceito de proporção é fundamental para entender a escala geográfica, ao comparar diferentes espaços e escalas de análise, relacionando o local e o global (CASTELLAR, 2005) 


\subsubsection{Aplicação de atividades práticas referentes ao eixo temático A}

Após a apresentação das propostas criadas pelos participantes, foi feita pelo ministrante da oficina a aplicação de duas atividades práticas referentes a Lateralidade e Orientação, presente no eixo temático A. Esse momento corresponde a apresentação de atividades práticas já realizadas na Educação Básica pelos pesquisadores, colaborando para novas estratégias metodológicas sobre Cartografia Escolar. Logo, apresenta-se a descrição dessas atividades e relatos quanto suas aplicações durante a oficina.

\subsubsection{Atividade sobre lateralidade: a "dança das cadeiras"}

A atividade tem como objetivo trabalhar especificamente com as noções de lateralidade. Ela corresponde a uma adaptação da atividade proposta por Da Silva et al., (2018), no qual desenvolveu uma sequência didática de atividades referentes a temática, aplicadas na Educação Básica. Na proposta do autor, os alunos eram convidados, inicialmente, a formarem círculos com cabos de vassouras em mãos, e a partir disso, dava-lhes a direção que deveriam se descolar (direita, esquerda, leste e oeste) a fim de os estudantes se movimentarem conforme a ordem estabelecida, sem deixar o cabo da vassoura cair. Assim, a cada rodada, o aluno que errava a direção ou deixava a vassoura cair, era "eliminado", vencendo a "competição" aquele que permanecesse mais tempo no círculo (DA SILVA et al., 2018).

Para o desenvolvimento dessa atividade com os professores em formação, adaptou-se os cabos de vassouras por cadeiras, ocasionando o mesmo processo da dinâmica, a fìm de exemplificar atividades referentes a temática e contribuir para formação docente, enquanto estratégias metodológicas sobre linguagem cartográfica. Observou-se grande envolvimento dos participantes na realização desta atividade e muita curiosidade sobre as propostas desenvolvidas. Além disso, relataram a motivação em realizar a oficina e destacaram que sanaram muitas dúvidas quanto ao tema abordado. Nesse momento, os participantes também propuseram trabalhar as noções de orientação usando as lógicas das cadeiras. Todavia, houve dificuldades em consolidar a atividade, devido à problemas de orientação. Castrogiovanni (2014, p. 28) destaca que: "Para que uma criança se oriente no espaço, é necessário que se oriente no seu próprio corpo", o que denota que na escola seria interessante fomentar atividades prévias utilizando os conceitos de lateralidade com os alunos.

No decorrer da atividade, pode-se observar que os sujeitos da pesquisa se sentiram motivados, participando ativamente em todo processo. Todavia, em determinados momentos da aplicação, observou-se dificuldades na orientação espacial frente ao tabuleiro montado, ou seja, para o desenvolvimento da atividade é necessário a boa interpretação e discussão prévia sobre as noções relacionadas aos pontos de referências de acordo com o referencial adotado. Ademais, a 
atividade foi validada enquanto estratégia metodológica para Educação Básica, auxiliando a expansão dos conhecimentos dos participantes em relação a aplicação de atividades de Cartografia na escola.

A oficina didática 2 pode ser analisada quanto a dois objetivos propostos no trabalho. No que se refere a aplicação de atividades práticas com os integrantes, elas contribuíram para formação docente, despertando diversas possibilidades enquanto sua aplicação na Educação Básica, bem como motivaram os estudantes durante o curso. Nas atividades criadas pelos sujeitos das pesquisas, elas possuem potencial de aplicação nas escolas, devido a suas facilidades metodológicas, bem como o uso de materiais acessíveis em diversos contextos escolas. Além disso, com a realização do objetivo proposto, no ato dos participantes criarem as atividades, nota-se a presença de um estudo referente a linguagem cartográfica, desmistificando o medo e receio de trabalhar com essa temática.

Quanto ao caráter metodológico adotado na oficina para os professores em formação, algumas mudanças podem ser feitas para futuras realizações do curso de extensão. Dentre essas modificações, pode-se inserir a realização de um debate expositivo-dialogado sobre cada item presente nos eixos temáticos, a fim de facilitar melhor compreensão de todos durante o curso. Podese também inverter a ordem da oficina, isto é, no primeiro momento apresentar as atividades já desenvolvidas na escola e, no segundo momento, os participantes apresentam as atividades criadas de acordo com suas investigações sobre a temática. Essa mudança metodológica pode contribuir na perspectiva que tanto as oficinas criadas pelo público-alvo, quanto as apresentadas pelo pesquisador, são importantes no processo de ensino-aprendizagem. Dessa forma, essa mudança pode ocasionar a horizontalidade entre as propostas pedagógicas, não idealizando que as atividades já aplicadas na escola são mais importantes e norteadoras do processo didático.

\subsection{Oficina didática 3 - Construção de atividades sobre alfabetização e letramento cartográfico}

Para trabalhar a temática "Coordenadas geográficas e projeções cartográficas”, o grupo responsável pelo eixo organizou duas atividades. A primeira atividade consiste em trabalhar com as projeções cartográficas a partir de globos terrestres criados em bolas de isopor e folhas com diferentes projeções cartográficas. A partir da confecção desses objetos, os participantes sugerem o aprofundamento das projeções cartográficos, oportunizando a relação entre teoria e prática. Para o desenvolvimento de uma atividade sobre coordenadas geográficas, o grupo apresentou a proposta de desenvolver um "caça ao tesouro", de acordo com a realidade das escolas na qual a atividade poderá ser aplicada. A partir desse caça ao tesouro, as pistas para encontrar determinado objeto seriam dadas por meio de coordenadas geográficas. O grupo não realizou prática das atividades 
durante a oficina, porém entregou o plano de aula. Ainda se destaca que as duas ideias de práticas foram copiadas da disciplina de Cartografia Geral.

Com base nas ideias levantadas pelos grupos, os integrantes relataram outras metodologias que podem ser eficazes para trabalhar coordenadas geográficas e projeções cartográficas. Dentre essas metodologias, foi debatido a questão de ampliar o tabuleiro feito na oficina anterior, sobre o viés das coordenadas, isto é, traçar sobre o tabuleiro os paralelos e meridianos e criar cartelas que envolvessem as coordenadas, como por exemplo, "saindo de $40^{\circ}$ Norte, percorra $20^{\circ}$ para Sul". Além disso, os participantes relataram que as coordenadas podem ser trabalhadas na perspectiva do jogo de batalha naval .

No que se refere as projeções cartográficas, foi relatado que as mesmas podem ser trabalhadas com o auxílio das geotecnologias. Dessa forma, indicou-se o software Flex Projector como um meio de manusear as projeções no espaço escolar. O Flex Projector corresponde em um software que ilustra ao usuário diversas projeções cartográficas, enfatizando suas distorções e formas de representar o mundo. Logo, pode ser utilizado na escola como meio de mostrar aos estudantes outras formas de representações da Terra, diferenciando das projeções clássicas presentes nos livros didáticos de Geografia.

Ademais, durante o debate sobre o eixo temático, os participantes enfatizaram o papel das projeções cartográficas sobre a questão geopolítica mundial e o poder dos mapas frente a intencionalidade de quem o elabora. Harley (2009, p. 27) destca que "o cartógrafo nunca foi um artista, um artesão ou um técnico independente. Por trás do criador dos mapas se esconde um conjunto de relações de poder, que cria suas próprias especificações”. Nesse sentido, debateu-se a importância da Cartografia como recurso didático para trabalhar diversos fenômenos geográficos, exemplificando as projeções de Mercator e Peters como formas de representar o mundo em diferentes contextos da sociedade, ocasionando uma visão sistêmica da Cartografia com diversas áreas do conhecimento.

Os integrantes do grupo responsável pelo eixo temático "Gráficos, cartogramas e geotecnologias" optaram por trabalhar exclusivamente com cartogramas. Dessa forma, o grupo realizou uma apresentação enfatizando os diversos contextos que os cartogramas podem ser trabalhados nas aulas de Geografia, sendo um método importante para representar determinado dado ou fenômeno geográfico.

O grupo do eixo temático sugeriu como atividade prática a realização de cartogramas que valorizassem determinado assunto presente no espaço vivido dos participantes, a fim de aplicar a noção de Letramento Cartográfico. Para isso, o grupo apresentou dados referentes a assistência

\footnotetext{
${ }^{6}$ Consiste em um jogo de tabuleiro de dois jogadores, no qual os jogadores têm de adivinhar em que quadrados estão os navios do oponente, a fim de destruir os navios dos inimigos. Para adivinhar os quadrados, os participantes precisam informar coordenadas expostas no tabuleiro, ocasionando a localização de todo corpo do navio no jogo.
} 
estudantil da Universidade $\mathrm{X}$, espaço referente ao cotidiano dos sujeitos da pesquisa, e a partir desses dados, os estudantes criaram cartogramas que ilustrassem essas informações (Figura 4).

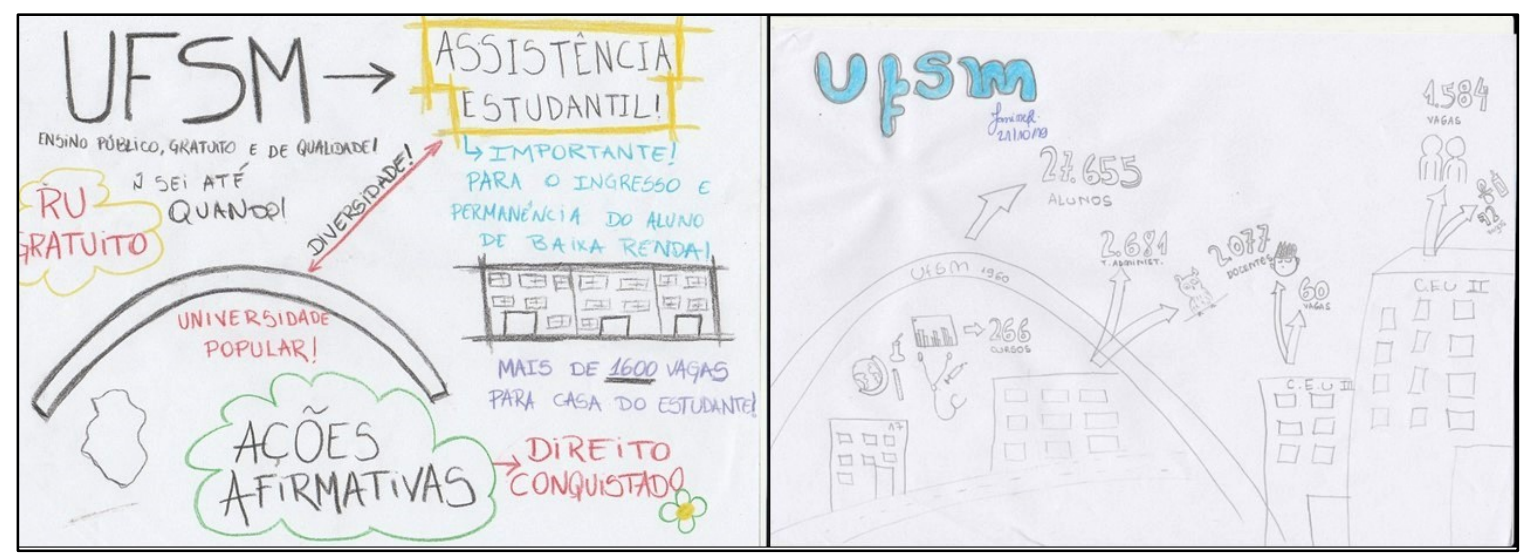

Figura 4 - Cartogramas criados pelos participantes da oficina.

Durante a atividade, iniciou-se um debate sobre a importância de valorizar o espaço de vivência dos discentes, seja na escola ou no Ensino Superior. Callai (2005) corrobora com este pensamento: “do ponto de vista da Geografia, esta é a perspectiva para se estudar o espaço: olhando em volta, percebendo o que existe, sabendo analisar as paisagens como o momento instantâneo de uma história que vai acontecendo (CALLAI, 2005, p. 235). Assim, notou-se a compreensão dos estudantes acerca da teoria norteadora do Letramento Cartográfico. Com o fim da elaboração dos cartogramas, cada sujeito da pesquisa apresentou seu cartograma e realizaram um debate sobre a intencionalidade de quem elabora os produtos cartográficos, resultado de diferentes percepções e visões de mundo sobre os fenômenos espaciais.

Com base nos produtos realizados pelos participantes e nas observações realizadas pelo pesquisador durante a apresentação e realização da atividade proposta, salienta-se que a dinâmica contribuiu satisfatoriamente com a proposta da oficina, oportunizando debates significativos de assuntos que norteiam a realidade dos professores em formação das universidades públicas do Brasil, em específico, a realidade da instituição o qual está sendo realizado o trabalho. No entanto, quanto a característica dos produtos cartográficos, os mesmos, dependendo da conceituação desse produto, não ser classificados como cartograma, visto que desconsideram o valor quantitativo dessa representação cartográfica. No que se refere ao Plano de aula da atividade proposta, não houve envio e/ou entrega pelos integrantes do grupo que propôs a atividade.

Com o objetivo de trabalhar a interpretação de quadros, foi desenvolvido na oficina a elaboração manual ${ }^{7}$ de Mapas Coropléticos $^{8}$, com base na relação entre quadros e mapas. A

\footnotetext{
${ }^{7}$ Adotou-se realizar, em primeiro momento, a elaboração de Mapas Coropléticos manuais, a fim de na próxima oficina, realizar esses mesmos mapas com Sistemas de Informação Geográfica.

${ }^{8}$ Segundo Martinelli (1998, p.92), Mapa Coroplético corresponde ao um mapa que "estabelece que a ordem dos valores relativos, agrupados em classes significativas, seja transcrita seguindo uma ordem visual das cores, indo das mais claras
} 
variável adotada para elaboração dos mapas foi a população total da área urbana do município de Santa Maria/RS, bem como a população de homens e mulheres.

A partir do exposto, foi entregue aos estudantes um quadro com a população de Santa Maria por bairro, e um esboço do contorno da área urbana do município para construção dos mapas. As informações presentes no quadro foram extraídas Sistema IBGE de Recuperação Automática (SIDRA), correspondente ao ano de 2010, e a malha de Santa Maria para elaboração do mapa, foi através do Instituto Brasileiro de Geografia e Estatística (IBGE), e posteriormente, estruturado no software de mapeamento QGIS (Oficina 4).

Convém destacar, que durante a elaboração dos mapas, os sujeitos de pesquisa debateram sobre questões sociais referentes ao espaço mapeado, bem como a importância na elaboração de mapas referentes a outras realidades que integram o espaço urbano, tais como feminicídio e espacialidade dos transportes urbanos sobre o território. Além disso, relataram a fidelidade das informações presentes nos mapas em relação a sociedade, ou seja, que se houver distorções e generalizações no produto cartográfico, não correspondendo com a realidade do espaço mapeado, o mesmo poderá confundir o leitor do mapa, além de não contribuir para as esferas do planejamento rural, urbano e ambiental. Em relação a Alfabetização e Letramento Cartográfico, durante a oficina, evidenciou-se a compreensão dos sujeitos quanto a temática, mostrando evolução quanto as especificidades da Cartografia, bem como o uso de termos característicos do tema, como por exemplo, a relevância do termo espaço vivido durante o desenvolvimento das atividades.

\subsection{Oficina didática 4 - Construção de atividades sobre alfabetização e letramento cartográfico}

As geotecnologias podem ser utilizadas como uma técnica de suporte ao processo de Alfabetização Cartográfica, auxiliando no processo de interpretação de fenômenos geográficos. Por esse motivo, foi escolhido finalizar o curso de extensão com o uso dessa tecnologia, a fim de mostrar alternativas didáticas para trabalhar esse conhecimento na atualidade.

Por se tratar da predominância de estudantes do segundo semestre do curso, foi durante esse encontro que tiveram o primeiro contato com o software. Logo, visualizou-se que alguns sujeitos da pesquisa obtiveram dificuldades em manusear o QGIS, sendo necessário criar momentos de passo a passo para realização dos mapas. Todavia, as dificuldades principais se relacionavam a alfabetização tecnológica, ou seja, saber usar o computador corretamente. Di Maio e Setzer (2011, p. 215) destacam que a dificuldade enfrentada na "formação de professores no uso de novas tecnologias e o desenvolvimento de materiais adequados para fins educacionais no ensino básico".

até as mais escuras, ou seguindo uma ordem visual construída com texturas, que vão também das mais claras até as mais escuras" (MARTINELLI, 1998, p.92). 
A oficina possibilitou a inserção dos participantes ao trabalho com a geotecnologia. Além disso, por meio da elaboração dos mapas, os estudantes revisaram alguns elementos/conceitos realizados em momentos anteriores, tais como escala, legenda, orientação, projeção e coordenadas. Sendo assim, a oficina serviu como espaço para os participantes visualizarem a evolução do procedimento metodológico utilizado.

As principais dificuldades apresentadas em relação à manipulação dos dados dentro do ambiente do Sistema de Informação Geográfica se remeteram a organização das camadas de informações e o entendimento que havia diferentes escalas presentes no banco de dados. Por exemplo, o arquivo shapefile dos países da América do Sul deveria ser o primeiro a ser desenhado enquanto camadas de maior detalhe estariam inseridas dentro do shapefile do Brasil, do Rio Grande do Sul, de Santa Maria, da área urbana e assim sucessivamente (Figura 5).

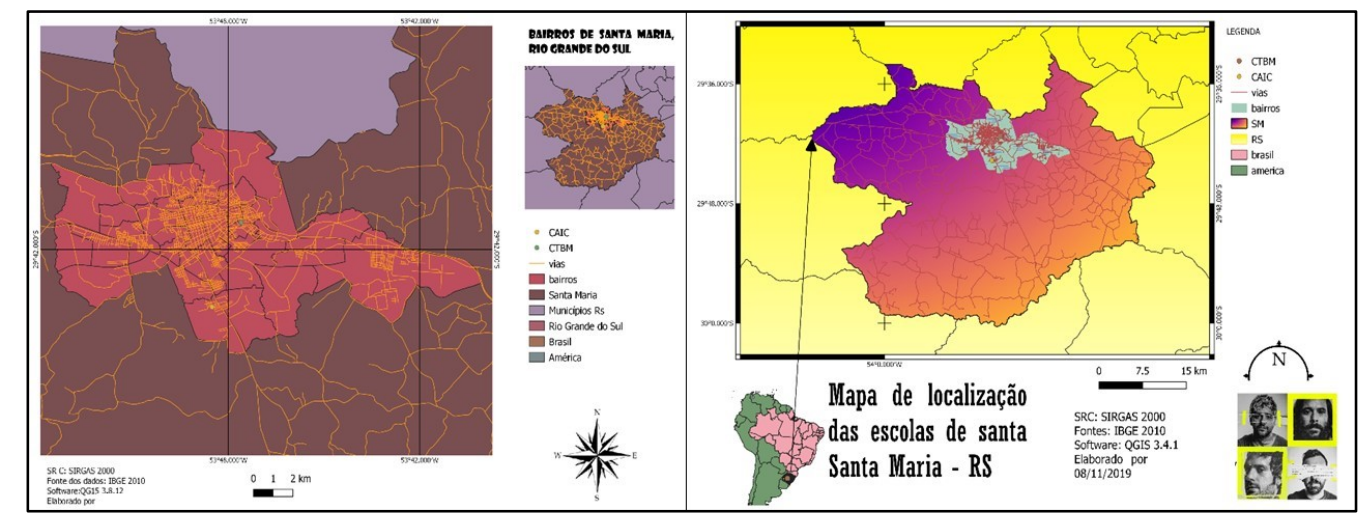

Figura 5 - Mapas criados pelos participantes da oficina.

Com base nos mapas elaborados pelos participantes, analisa-se que os mesmos usaram a criatividade para a criação dos produtos cartográficos, bem como apresentaram todos os elementos que compõem um mapa. Assim, após a elaboração dos mapas manuais dessa variável, os participantes visualizaram todo procedimento sobre a base tecnológica, principalmente em como o software realiza a organização das classes presentes na variável do mapa. Ademais, o uso das geotecnologias constitue mais uma ferramenta aliada ao ensino de Geografia, conforme Santos et al. (2011) abordam que é necessário o uso de diversos recursos didáticos para fomentar as relações que se estabeleceram entre a cartografia e o ensino da Geografia.

Após a aplicação da atividade voltada ao uso da geotecnologia, a segunda parte da oficina correspondeu à análise das metodologias adotadas em todo curso de extensão. Dessa forma, os participantes foram convidados a relatarem suas percepções (Figura 6). Ao analisar a figura com as palavras que os participantes escreveram na primeira oficina (Figura 3), percebe-se que houve a inserção de novos termos para caracterizar a linguagem cartográfica, principalmente termos ligados a metodologia criada referente a Alfabetização e Letramento Cartográfico e das ferramentas 
utilizadas para criar as representações cartográficas, como por exemplo, geotecnologias, alfabeto cartográfico, tipos de visões e espaço vivido.

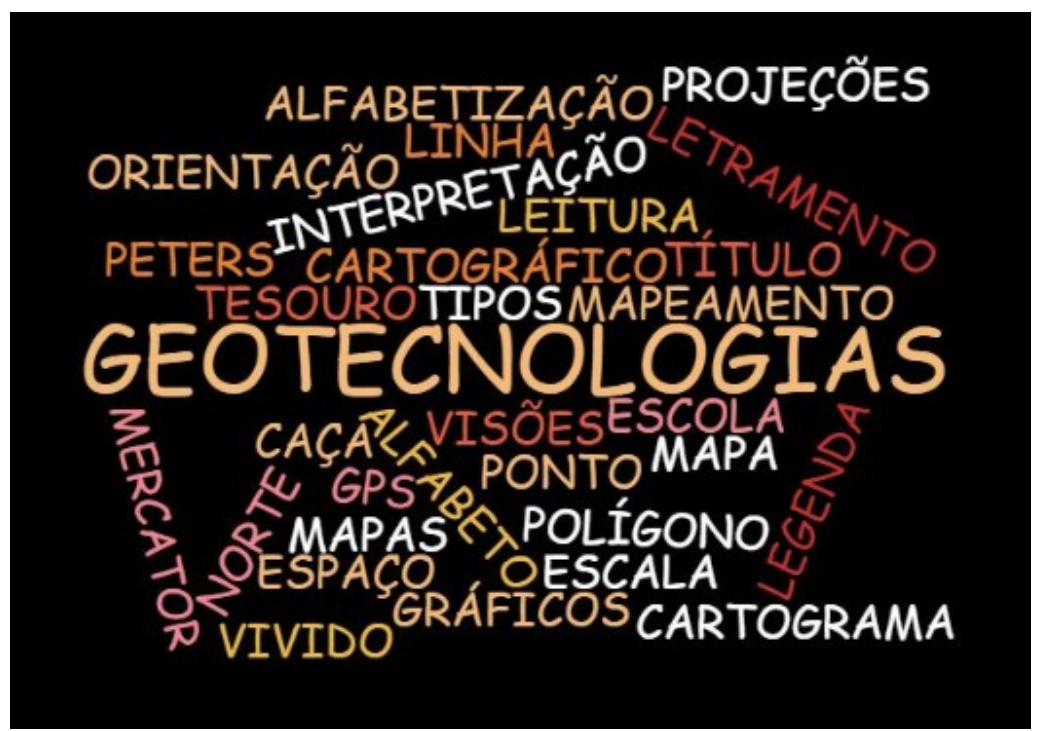

Figura 6 - Principais palavras escritas pelos sujeitos da pesquisa que caracterizam a Cartografia Escolar após a participação das oficinas didáticas.

Fonte: Organizado pelo autor no software Wordclouds.

Após a análise das novas interpretações que os participantes possuem sobre Cartografia Escolar, apresenta-se no quadro a seguir algumas avaliações realizadas sobre a metodologia desenvolvida nas oficinas didáticas (Quadro 4).

Quadro 4: Avaliações dos sujeitos da pesquisa quanto as oficinas realizadas no curso de extensão.

\section{Síntese das respostas dos sujeitos da pesquisa}

01. Após a conclusão da formação, ao analisar os encontros, é possível concluir que foram de grande relevância, tendo em vista que se fazem necessárias para formação de futuros professores. Ainda, que é de extrema importância para ampliar nossas visões sobre o assunto, e desmistificar temas muitas vezes poucos abordados na Educação Básica.

02. O projeto foi de suma importância para a formação dos participantes. Pois, foi possível visualizar a aplicação da Cartografia dentro e fora de sala de aula. Ademais, poderemos aplicar estas oficinas para nossos futuros alunos.

03. Metodologia de fácil entendimento e relevantes para a formação inicial de professores.

04. Ótima iniciativa e pelas excelentes exposições submetidas, certamente ajudará minha formação profissional como licenciada. As brincadeiras e dicas foram muito úteis e práticas, coisas simples que aguçam a curiosidade dos alunos, auxiliando no aprendizado. Agradeço pela oportunidade!

05. Formações relevantes e organizadas.

06. Pensar Cartografia sempre foi difícil. No entanto, com a realização do curso de extensão, as oficinas contribuíram para pensar a Cartografia como valioso instrumento pedagógico.

Com base nas respostas, percebe-se o apreço dos participantes acerca das estratégias metodológicas desenvolvidas na oficina. Convém destacar, que as oficinas foram encerradas com a participação efetiva dos participantes em todo processo, contribuindo para trocas de experiências e construção de ideias que oportunizam o conhecimento cartográfico. 


\section{CONSIDERAÇÕES FINAIS}

A humanidade ao longo de sua história sempre utilizou as representações cartográficas como forma de entender a dinâmica presente no espaço geográfico. Essas representações, repletas de intencionalidade, tornou-se uma linguagem essencial na exposição material dos fenômenos espaciais. Dessa forma, a Cartografia consolidou-se como técnica de diversos contextos sociais, sendo de suma importância trabalhar seus signos e potencialidades na Educação Básica. No entanto, pouco se tem espaço para debater as noções de Cartografia Escolar nos cursos de formação inicial de professores, no qual ainda prevalecem as noções cartográficas trabalhadas sob a ótica manual, sistemática e tradicional, isto é, não valorizando as múltiplas possibilidades de instigar o pensamento cartográfico na atualidade, conforme foi relatado pelos participantes no início do curso de extensão. Por essa razão, o presente trabalho buscou pensar em desenvolver oficinas, fundamentadas em pesquisas da temática, que valorizem a inserção de debates em diferentes contextos sociais, a fim de contribuir para o estudo cartográfico em públicos que utilizarão esses conhecimentos durante a prática docente.

No que se refere as atividades criadas pelos participantes, notou-se a criatividade e compromisso de criar recursos didáticos condizentes a temática. A oficina criada pelo eixo temático I, o qual foi denominada de "Mega Senha", condiciona a revisão dos assuntos revisados, tornando essa etapa da disciplina lúdica e participativa. A oficina referente ao eixo temático II (proporção, escala e legenda) proporciona a visualização prática sobre as noções de escala cartográfica, mostrando a relação do espaço mapeado para o papel, isto é, da redução e noções matemáticas presentes nessa metodologia. A oficina do eixo temático III (coordenadas geográficas e projeções cartográficas) oportunizam o entendimento dessas noções por meio de jogos e atividades ligadas ao lúdico. Embora, se destaque que apesar dos alunos terem a noção de como fazer a atividade, muitos grupos não se sentiram confortáveis para realizarem a aplicação da prática ou entregarem o plano de ensino.

No que se refere a oficina do eixo temático IV (gráficos e cartogramas), esta apresenta potencialidade na criação de produtos cartográficos e aplicação desses produtos sobre a realidade que tange os contextos escolares, condicionando o pensar crítico sobre as representações gráficas e a realidade do espaço vivido. Além disso, essa atividade oportuniza ao estudante entender sobre os procedimentos realizados na construção desses produtos. Nesse sentido, as oficinas mostram recursos didáticos para aplicação na Educação Básica, contribuindo para construção pensamento espacial que colabora ao desenvolvimento do raciocínio geográfico, conforme debatido pela normativa educacional brasileira. 
Outro fator importante para ser destacado é a diferença de semestres dos sujeitos da pesquisa no curso superior e a inserção desses participantes em projetos de iniciação à docência. Essa característica foi evidenciada durante as oficinas, seja no debate expositivo-dialogado da temática, seja na elaboração de Planos de Aula e atividades práticas. Nessa perspectiva, é importante pensar as oficinas sobre a realidade dos sujeitos da pesquisa, valorizando suas dificuldades e experiências ao longo da formação docente e cidadã.

Durante a realização das oficinas pedagógicas, pode-se analisar pelo pesquisador que elas oportunizaram o debate de diferentes assuntos que emergem a realidade do professor em Geografia, seja na teoria cientifica da Cartografia Escolar, seja na necessidade de pensar essas representações perante os fenômenos geográficos que integram a realidade discente, ocasionando o pensar crítico, social e emancipador do estudante sobre seu espaço vivido, sobretudo na oficina 3 onde temáticas sobre a assistência social nas Universidades públicas, questões políticas e feminicídio. Logo, a oficina pedagógica além de trabalhar as noções especificas da linguagem cartográfica, debateu questões importantes referentes as pedagogias educacionais e a necessidade de pensar a realidade do estudante da Educação Básica. Esse fator é de suma importância durante a formação inicial, pois integra diferentes áreas do conhecimento e atribui a formação completa do docente frente a multiplicidade teórica e pedagógica da escola na atualidade. Todavia, as oficinas didáticas realizadas não podem ser classificadas como finalizadas, visto que a linguagem cartográfica é muito dinâmica, no qual sempre emerge novos conceitos para entender a multiplicidade metodológica que a mesma propicia a seus estudantes e usuários.

Isso posto, algumas alterações podem ser feitas quanto a realização da metodologia desenvolvida para as oficinas. Ao aplicar a sequência de oficinas com os sujeitos da pesquisa, notou-se algumas dificuldades dos participantes quanto ao desenvolvimento e criação de atividades voltadas a determinados conceitos referentes ao Letramento Cartográfico. Logo, uma mudança significativa para novas aplicações das oficinas, é a realização de um debate expositivo-dialogado sobre cada conceito norteador da Cartografia, isto é, tipos de visões, tipos de imagens, cartograma, entre outros. Essa ideia poderá contribuir na realização de novas atividades práticas, condicionando o sujeito a conhecer cada termo para desenvolver suas atividades.

Assim, é necessário enfatizar que a metodologia desenvolvida no trabalho precisa se adequar aos diferentes contextos sociais dos espaços escolares, estando aptas a serem adaptadas frente a realidade escolar, isto é, presença ou não de materiais didáticos, público que frequenta a escola, conhecimento prévios dos estudantes sobre a área do conhecimento, entre outros. Isso é primordial para ser pensado na formação inicial docente, a fim de não idealizar a escola como um espaço no qual qualquer metodologia criada pode ser aplicada satisfatoriamente, mas sim que a 
mesma possui diversos aspectos pedagógicos e sociais que podem afetar diretamente a prática docente.

Logo, conclui-se que o presente trabalho visou contribuir para as carências curriculares nos cursos superiores sobre Cartografia Escolar, valorizando uma formação docente voltada a importância do pensar cartográfico em suas práticas em sala de aula. Assim, espera-se que o trabalho ganhe espaços em debates acadêmicos, seja na leitura da síntese teórica apresentada, seja na aplicação efetiva das oficinas didáticas desenvolvidas.

\section{REFERÊNCIAS}

ALMEIDA, R. D. Do desenho ao mapa: iniciação cartográfica na escola. São Paulo: Contexto, 2001. 107p.

ALMEIDA, R. D. Novos rumos da Cartografia Escolar. São Paulo: Contexto, 2011. 192p.

ALMEIDA, R. D. Uma proposta metodológica para a compreensão de mapas geográficos. In: ALMEIDA, R. D. (Org.). Cartografia Escolar. São Paulo: Contexto, 2014, p. 145-118.

ARAGÃO, W. A. Cartografia Escolar: experiências no ensino fundamental II e no ensino médio. In: ENCONTRO NACIONAL DE GEÓGRAFOS. 16., 2010, Porto Alegre. Anais... Porto Alegre: 2010.p. 1-5.

BATISTA, N. L.; BECKER, E. L. S.; CASSOL, R. Multiletramentos e multimodalidade na cartografia escolar para o ensino de geografia: considerações gerais. Para Onde!?, Porto Alegre, v. 12, n. 2, p. 01-10, 2019.

BONA, A. S.; VELHO, L. F.; SILVA, S. L. C. da; PETSCH, C. Matemática em Diferentes Contextos: um recorte do curso MOOC colaborativo na área da Cartografia. In: FREITAS, P. G.; MELLO, R. G. (Org.). Tecnologias digitais e inovação em práticas de ensino. Rio de Janeiro: ePublicar, 2020a, p. 324-344.

BREDA, T. V. "Por que eu tenho que trabalhar lateralidade?": experiências formativas com professoras dos anos iniciais. 2017. 290 f. Tese (Doutorado em Ciências) - Universidade Estadual de Campinas, Campinas, 2017.

CALLAI, H. C. Aprendendo a ler o mundo: a geografia nos anos iniciais do ensino fundamental. Caderno CEDES, Campinas, v. 25, n. 66, p. 227-247, 2005

CASTELLAR, S. M. V. Educação geográfica: a psicogenética e o conhecimento escolar. Caderno CEDES, Campinas, n. 25, p. 209-225, 2005.

CASTROGIOVANNI, A. C. Apreensão e compreensão do espaço geográfico. In: CASTROGIOVANNI, A. C (Org.). Ensino de Geografia: práticas e textualizações no cotidiano. Porto Alegre: Mediação, 2014.

CAVALCANTI, L. S. Geografia e prática de ensino. Goiânia: Alternativa, 2002. 
DI MAIO, A. C.; SETZER, A. W. Educação, Geografia e o desafio de novas tecnologias. Revista Portuguesa de Educação, v. 24, n. 2, p. 211-241, 2011.

FARACO, C. A. Norma culta Brasileira: desatando alguns nós. São Paulo: Parábola Editorial, 2008. 224p.

HARLEY, B. Mapas, saber e poder. Confins, n. 5, 2009.

MARTINELLI, M. Alfabetização Cartográfica. Boletim de Geografia da UEM, Maringá, v. 01, n. 17, p. 125-130, 1999.

OLIVEIRA, L. Estudo metodológico e cognitivo do mapa. 1978. 128 f. (Tese de Livre Docência) - Instituto de Geociências, Universidade Estadual Paulista, Rio Claro, 1978.

OLIVEIRA, I. J.; NASCIMENTO, D. T. F. As geotecnologias e o ensino de cartografia nas escolas: potencialidades e restrições. Revista Brasileira de Educação em Geografia, v. 7, p. 158-172, 2017.

PASSINI, E. Y. Alfabetização cartográfica e a aprendizagem de Geografia. São Paulo: Cortez, 2012. 216p.

RICHTER, D. A linguagem cartográfica no ensino de Geografia. Revista Brasileira de Educação em Geografia, v. 7, p. 277-300, 2017.

RICHARDSON, R. J. Pesquisa Social: métodos e técnicas. São Paulo: Atlas, 1985. 424p.

RIZZATTI, M. Cartografia Escolar, geotecnologias e a Teoria das Inteligências Múltiplas: a construção de conhecimentos geográficos no ensino fundamental. 2016. 110 f. Monografia (Trabalho de Graduação em Geografia) - Centro de Ciências Naturais e Exatas, Universidade Federal de Santa Maria, Santa Maria, 2016.

SANTOS, C.; PEDROTTI, A.; MATOS, A. L.; SANTANA, A. P. S. A Cartografia e o ensino da Geografia. Revista Geográfica de América Central, n. especial EGAL, p. 1-15, 2011.

SANTOS, F. A cartografia escolar e sua importância para o ensino de Geografia. Caderno de Geografia, Belo Horizonte, v. 27, n. 50, p. 500-515, 2017.

DA SILVA, G. M.; BATISTA, N. L.; RIZZATTI, M.; CASSOL, R.; A Cartografia Escolar como ferramenta pedagógica no ensino de Geografia: uma proposta de Oficinas Didáticas com alunos do Ensino Fundamental. Revista Ensino de Geografia, Recife, v. 1, p. 120-134, 2018.

SIMIELLI, M. E. R. Visão cartográfica: Referência Teórico Metodológica. São Paulo: USP, 1996.

SIMIELLI, M. E. R. Cartografia no ensino fundamental e médio. In: CARLOS, A. F. A. (Org.). A Geografia na sala de aula. São Paulo: Contexto, 1999.

TRIVIÑOS, A. N. S. Introdução à pesquisa em Ciências Sociais: A pesquisa qualitativa em Educação. São Paulo: Atlas, 2006. 175p. 